\title{
A critical analysis on the use of herbs and herbal extracts in feeding sport horses
}

\author{
Domenico Bergero and Emanuela Valle \\ Department of Animal Production, Epidemiology and Ecology, University of Torino, Grugliasco (TO), Italy
}

\begin{abstract}
Summary
In human and veterinary medicine there is an increasing interest to find new natural substances, mainly herbal derivates, that improve biological function and increase the body health. The aim of this paper is to analyse the use of some herbals supplements formulated for sport horses. Infact herbs are considered a very important resource as health-promoting substances and new substances for oral administration and specific supplements are on the market. Methods and results: We have analysed the main claimed ergogenic effects of herbal products such as boosting immune system, improving performance, improve antioxidant status and general stress and improve attention. In particular we have analysed the label claims and the possibility of collateral effects and doping interaction of some common herbal extracts. Clinical relevance: In the last years, herbal products underwent a great increase of their distribution both in the human and veterinary medicine, particularly in the horse market. The absence of common regulatory control over herbal products have two effects: from one hand, it is hard to recognize good products from others that are of very poor quality; from the other, the consumer could be sometime exposed to the risk of intoxication. Conclusion: The effect claimed for these supplements vary widely. They often include ergogenic effects or promoting welfare. However there are a few studies on the real effect of many herbal products and premixes containing herbal products for horses.
\end{abstract}

Keywords: horse, herbal extract, ergogenic aids, doping, nutrition

\section{Zum Einsatz von Kräuterextrakten in der Fütterung des Sportpferdes}

Sowohl in der Human- als auch in der Tiermedizin gibt es ein großes Interesse daran, natürliche Substanzen, in erster Linie Kräuterderivate, zu finden, welche die biologische Funktion und körperliche Gesundheit verbessern. Das Angebot solcher Zusatzmittel hat speziell auf dem Pferdemarkt in den letzten Jahren stark zugenommen. Ziel des Beitrags ist es, den Gebrauch einiger Kräuter-Ergänzungsfuttermittel für Sportpferde zu untersuchen. Tatsächlich wird davon ausgegangen, dass Kräuter eine wichtige Quelle gesundheitsstützender Substanzen darstellen und es sind neve Formulierungen zur oralen Anwendung und spezifische Supplemente auf dem Markt. Wir haben die wichtigsten angegebenen ergogenischen Wirkungen von Kräuterprodukten untersucht, wie Anregung des Immunsystems, Leistungssteigerung, Verbessrung des antioxidativen Status und der allgemeinen Stressbelastung sowie die Verbesserung der Aufmerksamkeit. Speziell untersuchten wir die Herstellerhinweise sowie mögliche Nebenwirkungen und Dopinginteraktionen einiger üblicher Kräuterextrakte. Das Fehlen allgemeiner Kontrollregularien für Kräuterextrakte hat zwei Folgen: Zum einen sind qualitativ gute Produkte von solchen schlechter Qualität nur schwer zu unterscheiden und zum andern kann das Pferd dem Risiko einer Intoxikation unterliegen. Die von den Herstellern behaupteten Wirkungen dieser Supplemente sind mannigfaltig, leider gibt es nur wenige Studien über die tatsächlichen Wirkungen von Kräuterprodukten und Pferdeergänzungsfutter mit Kräuterbeimischungen.

Schlüsselwörter: Kräuterextrakt, Fütterung, Doping, ergogenische Unterstützung

\section{Introduction}

The main goals for the correct feeding of horses is to provide them all the nutrients required to satisfy the organism's needs and all the substances that help the animal to avoid metabolic problems and to use energy substrates and different nutrients sources in proper way (Bergero 2004). In human and veterinary medicine there is an increasing interest to find new natural substances, mainly herbal derivates, that improve biological function and increase the body health. For this reasons, today it is widespread the use of a great variety of products, mainly dietary supplements and nutraceuticals, containing herbal products or extracts, essentially claimed to enhance horses' welfare and increase performances (Valle and Bergero 2005).

Plants have played a significant role in maintaining human health and improving the quality of human life for thousands of years. The World Health Organization estimated that about $80 \%$ of the earth's inhabitants use traditional medicine for their primary health care needs, which may involves the use of plant extracts or their active components (Craig 1999). Also in vete- rinary medicine, herbal products underwent a great increase of their distribution, particularly in the horse market. This fact can be ascribed to different factors: a sort of growing suspicion in the use of traditional drugs and an increase in the horses' health perception. Other factors are believed to contribute to the increasing trend of herbal utilization: the owner desire of being an active part in horse cares, the easy accessibility on the supplement market and the perception that herbs are safer because natural is considered to be a synonymous of welfare (Abebe 2002).

If we consider the traditional remedies we can find that herbs are the most used natural compounds. Humans have made use of as valuable components for cooking (seasoning, beverages), for cosmetics and dyes and also as medicines (Craig 1999). In particular the concept of using special vegetable based foods and other plant material for health promotion is nothing new. Hippocrates (400 B.C.) reported a very current concept "Let food be your medicine and medicine be your food". In fact many of Western Countries drugs had their ori- 
gin in a plant extract. The simplest example is given by salicylic acid (a precursor of aspirin) that was obtained from willow tree bark (Salix alba). Other practical examples are given by digitalis, used as a heart stimulant, derived from the foxglove plant (Digitalis purpurea) and psyllium (Plantago ovata seeds) which have laxative effect, due to the presence of mucilages that provide a bulking effect (Craig 1999). The term herbs is used loosely to refer not only to herbaceous plants but also to bark, roots, leaves, seeds, flowers and fruits of trees, shrubs, woody vines, and extracts of the same that are valued for their savory, aromatic, or medicinal qualities (Craig 1999).

For this reason nowadays there is great confusion in this fields and the border line between food and medicine is very thin. As a matter of fact, many herbs are used for cooking or as "culinary herbs" or species defined by the US Food and Drug Administration as "aromatic vegetable substances, in the whole, broken, or ground form, whose significant function in food is seasoning rather than nutrition. They are true to name, and from them no portion of any volatile oil or other flavoring principle has been removed" (Lampe 2003). They are used to flavour foods since antiquity. In most of these herbs, the flavour is provided by the aromatic ingredients in their essential oils and oleoresins. Paprika (Capsicum annuum L.) and turmeric (Curcuma longa), are a simple example of herbal flavouring that are used also in traditional medicine, whereas garlic (Allium sativum) or onion (Allium cepa) are considered not also as seasoning but as foods (Craig 1999, Pearson et al. 2005, Naganuma et al. 2006).

Nowadays herbs are considered an important resource as health-promoting substances. However the concept that herbals supplements are natural and - then - safe is fallacious. This consideration of safety derives from a long-term practice or usual exposure to the agent as a part of normal diet. In fact, herbs contain hundreds of phytochemicals compounds with different mechanisms of activities (Tsao and Aktar 2005).

More and more evidences have been produced about the importance of studying herbal products to identify their real effect and, more important, the absence of undesired side effects. In fact there is a lack a specific legislation that regulates the classification, marketing and safety evaluation of animal herbal supplements.

The picture is complicated by the variety of regulation in different countries, where an herbal product may be classified as an approved medicine remedy, dietary supplement or recreational herb.

In most countries of European Union there is no specific regulation on dietary supplements. Just a few countries as Germany have established commissions to asses the safety and efficacy of herbs at least in the human field. Commission E of the German Federal Health Agency published more than 300 monographs that evaluate the efficacy and safety of different herbal products according to acceptable clinical trials (Halsted 2003).

On the other hand, in countries such as Italy, the legislative situation has been reviewed both in the human and the veterinary fields. Many horse products containing herbs are available on the market such as "dietary supplements", but no study is required before they are presented to the market and no drug claims are allowed on the label advices. Herbs for hor- ses are then considered in Italy at the same time, ingredients for supplements or for mixed feeds (Valle and Bergero 2005). The absence of common regulatory control over herbal products has two effects: from one hand, it is hard to recognize good products from others that are of very poor quality; from the other, the consumer could be sometime exposed to the risk of toxicity.

Sometimes, it is considered that scientific studies are not requested for herbal products, since their use is confirmed by their anecdotical effect and safety. However, the traditional use of herbs is not always properly based on dosages, and moreover safety is not automatically provieded. As a matter of fact, whereas some herbal products may be useful and may contain active constituents that have beneficial physiological effects, others may be unsafe to use. Some herbs are safe at low dosage but they may be toxic at high dosage at least for man. For example, whereas Glycyrrhiza glabra (licorice) root can be used safely for treating duodenal and gastric ulcers, deaths, hypokaliemia, high blood pressure and hart failure are reported (Craig 1999).

Despite these considerations many industries, both food and drugs producing companies, have taken advantage from using herbal products and physicians have been actively pursuing this new area and have begun developing new products which claim to ensure a healthy life for the animal. So many food supplements contain herbals ingredients mixed with other substances such as minerals and vitamins or other well known compounds such as dimetilglycine, or BCCA.

The effect claimed for these supplements vary widely. They often include ergogenic effects or promoting welfare. However there are a few study on the real effect of many herbal products and herbal products containing premixes for horses. For this reason it is important to analyse the herbal supplements that are available on the market, to evaluate the real state of art. It is of utmost importance to get more scientific information to evaluate the benefits and the risks of these new horse herbal based supplements.

The aim of this paper is to analyse the use of some herbals supplements formulated for sport horses; we will consider the composition, as to herbal products, and the label claims of some products that are on the market in Italy; we will also considered the possibility of collateral effects and doping interaction of some common herbal extracts (Table 1).

\section{Are herbal products ergogenic substances?}

Ergogenic aid is an expression used to describe any agent, which can increase or improve work production or exercise performance (Hodgson and Rose 1994). Nowadays there is a great interest about ergogenic: a little change in the performance, in a race, could stand for the difference between to win or to loose. Adding a substance to the diets is believed to be more easy than to increase training effort and to be less risky. A recent report from Norway suggest that $84 \%$ of all national level competitors used some form of micronutrient supplement (Harris and Harris 2005).

Most of them contain herbal extracts to support performances in different approach. Possible ways to obtain this effect are claimed in different manners. 
Indeed, according to Harris and Harris (2005) ergogenic effects can be obtained in different ways, apart from improving equipment, training, nutrition, and pharmacological agents. They include improving psychological status, increa- sed level of available stored energy and efficiency in its conversion to work, improving coordination and flexibility, decreasing end products accumulation, reducing damage to tissues during exercise. Thus, ergogenics aids could improve

Table 1 Common name, formal name, claim, possible mechanism of action, clinical relevance and adverse discomfort of common herbacontaining in horse supplements.

Name, lat. Bezeichnung, Standort, mögliche Wirkmechanismen, klinische Bedeutung und Nebenwirkungen üblicher Kräuter in Pferde Supplements.

\begin{tabular}{|c|c|c|c|c|c|}
\hline $\begin{array}{l}\text { Common } \\
\text { name }\end{array}$ & Formal name & Claim & $\begin{array}{l}\text { Possible } \\
\text { mechanism of } \\
\text { action }\end{array}$ & $\begin{array}{l}\text { Clinical } \\
\text { relevance }\end{array}$ & $\begin{array}{l}\text { Adverse } \\
\text { discomfort }\end{array}$ \\
\hline $\begin{array}{l}\text { Bio- } \\
\text { flavonoids }\end{array}$ & $\begin{array}{l}\text { Purified } \\
\text { bioflavonoids or } \\
\text { herbal extracts } \\
\text { containing } \\
\text { flavonoids }\end{array}$ & $\begin{array}{l}\text { Improve } \\
\text { antioxidant } \\
\text { status }\end{array}$ & $\begin{array}{l}\text { Contrast ROS } \\
\text { formation } \\
\text { generated } \\
\text { during exercise, } \\
\text { inflammation } \\
\text { and by several } \\
\text { enzymes }\end{array}$ & $\begin{array}{l}\text { Preliminary studies } \\
\text { failed to find the } \\
\text { anecdotic referred } \\
\text { positive correlation } \\
\text { between } \\
\text { bioflavavonoids } \\
\text { use and some } \\
\text { performance } \\
\text { parameter } \\
\text { (Wooden et al., } \\
\text { 1984) (Sweeney et } \\
\text { al., 1984) }\end{array}$ & $\begin{array}{l}\text { No adverse } \\
\text { effects were } \\
\text { reported,but } \\
\text { more studies } \\
\text { are required }\end{array}$ \\
\hline
\end{tabular}

\begin{tabular}{|c|c|c|c|c|c|}
\hline $\begin{array}{l}\text { Schisandra } \\
\text { fruit, } \\
\text { Chinese } \\
\text { Mogno- } \\
\text { liovine fruit }\end{array}$ & $\begin{array}{l}\text { Scizandra } \\
\text { Chinensis }\end{array}$ & $\begin{array}{l}\text { Adapto- } \\
\text { genic }\end{array}$ & $\begin{array}{l}\text { Facilitates the } \\
\text { recovery of } \\
\text { sport horses in } \\
\text { training that } \\
\text { show high } \\
\text { levels of } \\
\text { transaminases } \\
\text { and CPK } \\
\text { (Hancke et al., } \\
\text { 1996) }\end{array}$ & $\begin{array}{l}\text { Preliminary studies } \\
\text { in the horse } \\
\text { showed a } \\
\text { decrease in CPK, } \\
\text { GGT and AST and } \\
\text { lactate values } \\
\text { (Hancke et al., } \\
\text { 1996; Valle et al., } \\
\text { 2005) }\end{array}$ & $\begin{array}{l}\text { No adverse } \\
\text { effects were } \\
\text { recommended, } \\
\text { but more } \\
\text { studies are } \\
\text { required }\end{array}$ \\
\hline
\end{tabular}

\section{Refereces}

Kirschvink N.,et al. (2002). Effect of nutritional antioxidant supplementation on systemic and pulmonary antioxidant status, airway inflammation and lung function in heaves-affected horses. Equine Veterinary Journal, 34: 705-712.

Wooden G.R.. et al., (1984) An investigation of the effect of hesperidin complex and lemon bioflavonoid complex on growth and development of thoroughbred horses. Journal of Animal Science, 59: 1529 1535.

Sweeney, C. R. ,et al., (1984)

Exercise-induced pulmonary hemorrhage in Thoroughbred horses: response to furosemide or hesperidincitrus bioflavinoids. Journal of the American Veterinary Medical Association, 185: 195-197.

Hancke J.L., et al., (1996) Reduction of serum hepatic transaminases and

CPK in sport horses with poor performance treated with a standardized Schizandra chinensis fruit extract. Phytomedicine, 3: 237-240

Ahumada F., eta I., (1989). Studies on the effect of Schizandra chinenensis extract on the horse submitted to exercise and maximum effort. Phytotherapy Research, 3: 175-179. Valle E., et al., Valutazione dell effetto del lavoro e dell efficacia di un integratore polifunzionale in cavalli trottatori in allenamento precoce. Ippologia in press.

$\begin{array}{lll}\text { St. John's Hypericum } & \text { Calmative } & \begin{array}{l}\text { Hyperforin has } \\ \text { wort }\end{array} \\ & \text { been shown to avaludies } \\ & \text { inhibit, like } \\ & \text { conventional } \\ & \text { antidepressants, } \\ & \text { the neuronal } \\ & \text { uptake of } \\ & \text { serotonin, } \\ & \text { norepinephrine } \\ & \text { and dopamine } \\ & \text { (Zanoli, 2004) }\end{array}$

Petazzi F. (2002). Photosensitization

Photo-

sensibilization

(Chabchoub et al., 1999) caused by Hypericum species.

Changes in the blood proteins of lonica goats. Summa, 19: 25-27 


\begin{tabular}{|c|c|c|c|c|c|c|}
\hline $\begin{array}{l}\text { Common } \\
\text { name }\end{array}$ & Formal name & Claim & $\begin{array}{l}\text { Possible } \\
\text { mechanism of } \\
\text { action }\end{array}$ & $\begin{array}{l}\text { Clinical } \\
\text { relevance }\end{array}$ & $\begin{array}{l}\text { Adverse } \\
\text { discomfort }\end{array}$ & Refereces \\
\hline $\begin{array}{l}\text { Cone- } \\
\text { flower }\end{array}$ & Echinacea spp & $\begin{array}{l}\text { Stimulates } \\
\text { immune } \\
\text { response, } \\
\text { haematinic } \\
\text { properties }\end{array}$ & $\begin{array}{l}\text { Stimulates } \\
\text { leucocyte } \\
\text { mobility, } \\
\text { phagocytosis } \\
\text { and T-cell } \\
\text { functions } \\
\left(O^{\prime} \text { Neill et al., }\right. \\
2002)\end{array}$ & $\begin{array}{l}\text { Clinical study in } \\
\text { the horse shows } \\
\text { effect after } 42 \\
\text { days of } \\
\text { treatments with } \\
\text { Echinacea } \\
\text { angustifolia } \\
\left(O^{\prime} \text { Neill et al., }\right. \\
2002)\end{array}$ & $\begin{array}{l}\text { No adverse } \\
\text { effects were } \\
\text { identify by } \\
\text { O'Neill et al., } 2002 \text {, but are } \\
\text { reported possible } \\
\text { drug interaction } \\
\text { in man (Abebe, } \\
\text { 2002) }\end{array}$ & $\begin{array}{l}\text { O Neill et al., (2002). } \\
\text { Immunological and haematinic } \\
\text { consequences of feeding a } \\
\text { standardised Echinacea (Echinacea } \\
\text { angustifolia) extract to healthy } \\
\text { horses. Equine Veterinary Journal, } \\
\text { 34: 222-227. } \\
\text { Abebe (2002). Herbal medication: } \\
\text { potential for adverse interactions witt } \\
\text { analgesic drugs. Journal of Clinical } \\
\text { Pharmacy and Therapeutics 27, } 391 \text { - } \\
401\end{array}$ \\
\hline Garlic & Allium sativum & $\begin{array}{l}\text { Anti- } \\
\text { parassitc, } \\
\text { Anti- } \\
\text { flammatory } \\
\text { Enhancer }\end{array}$ & $\begin{array}{l}\text { Organosulfour } \\
\text { compounds } \\
\text { provides the } \\
\text { basis for the } \\
\text { pharmacolocic } \\
\text { effect (Pearson } \\
\text { et al., 2005) }\end{array}$ & $\begin{array}{l}\text { Biochemical and } \\
\text { haematological } \\
\text { findings that were } \\
\text { indicative of } \\
\text { garlic tossicosis } \\
\text { are reported after } \\
\text { consuming } 0.2 \mathrm{~g} \\
\text { FDG } / \mathrm{kg} \\
\text { BID(Pearson et } \\
\text { al., } 2005\end{array}$ & $\begin{array}{l}\text { Heinz body } \\
\text { anemia, profuse } \\
\text { diaphoretic } \\
\text { response, } \\
\text { (Pearson et al., } \\
\text { 2005) urticara } \\
\text { (Miyazawa et al., } \\
\text { 1991) }\end{array}$ & $\begin{array}{l}\text { Person, et al., (2005) Association of } \\
\text { maximum voluntary dietary intake of } \\
\text { freeze-dried garlic with Heinz body } \\
\text { anemia in horses. American Journal } \\
\text { of Veterinary Research, 66: 457- } \\
464 . \\
\text { Miyazawa, et al., K. (1991). An } \\
\text { equine case of urticaria associated } \\
\text { with dry garlic feeding. Journal of } \\
\text { Veterinary Medical Science, 53: } 747 \text {. } \\
748\end{array}$ \\
\hline Valerian & $\begin{array}{l}\text { Valeriana } \\
\text { officinalis }\end{array}$ & Calmative & $\begin{array}{l}\text { Valerianic acid } \\
\text { increases GABA } \\
\text { levels in the } \\
\text { brain }\end{array}$ & $\begin{array}{l}\text { No studies } \\
\text { available }\end{array}$ & $\begin{array}{l}\text { Prohibited } \\
\text { substances of FEI } \\
\text { rules }\end{array}$ & $\begin{array}{l}\text { FEI Equine Prohibited List on } \\
\text { http:// } \\
\text { www.horsesport.org } \\
\text { No studies available in the horse }\end{array}$ \\
\hline
\end{tabular}

performance in different ways such as to increase mechanical energy for work, delaying the onset of fatigue, or improving neuromuscular coordination.

All this elements have a common target: producing and controlling energy utilization to allow an optimal sport performance. In addition we can include in this category of substances all those compounds that are capable of enhancing work performance across increasing the resistance to infections and improving general health. They can assist overall performance by reducing the sensibility to illnesses and infections, and then encourage the possibility of training or recovery from a competition (Harris and Harris 2005).

Herbs contain a great variety of bioactive agents characterized by several structure and different mechanisms of actions, and then different action (Craing 1999, Lampe 2003). Their use in the horse supplements is designed to enhance the fitness and health and consequently to improve performance. So it is possible to suppose that herbs are ergogenics aids. However there are some lacks on some herbal derivates scientific testing in the horse field. Tradition and analogy with human products represent the extend of validation for most herbs used for performance. Many herbal extract are used without an adequate knowledge of effects or side effects. For many herbals extracts there is no clinical evidence of ergogenics properties in the horse. Despite this consideration many supplements are available on the mark with ergogenic claims.

\section{Boost the immune system}

It is widespread opinion that sport horses are periled to different stress which can deteriorate the immune response. Immune system activity depends on several factors, such as nutrition and physical activity. In particular the protein depletion includes a loss of capacity of several essential functions of the immune system or the respiratory tract (Coenen 1998). Furthermore, strenuous or incorrect exercise has been recognized as a stressful condition, which can significantly alter the host's immune response and its susceptibility to disease. Several studies define the relationship among exercise and the immune response activity. If moderate training generally has beneficial effects on host defence mechanisms, highintensity exercise and overtraining might impair it. Exercise diminishes the lymphocyte function, and a decline in the number and cytolytic activity of natural killer cells; furthermore has detrimental effects on the immune system, e.g. suppressive effects, such as a decline in the ratio of CD4 + to CD8+ cells (Hines et al. 1996).

Aging and travelling stress are also known to affect immune function. Older horses had reduced immune function, but were more resistant to exercise-induced immune suppression than younger horses (Horohov et al. 1999). For this reason producing supplement for horses to support immune system activity appears to have real importance. 
Many products that report as a claim on the label: "Improves immune system" are available on the market; most of them contain nutrients, e.g. vitamins, and herbal extracts such as Echinacea. Echinacea is a flowering plant of the Asteraceae Family, native of eastern North America. The genus name is from the Greek echino, meaning "hedgehog", a reference to the spiny central disk. The Echinacea species traditionally used are: Echinacea angustifolia, Echinacea pallida, Echinacea purpurea. This species have a long history of medicinal use for a variety of conditions, particularly infections, and today echinacea products are among the best-selling human herbal preparations in several developed countries. Modern interest in Echinacea is focused on its immunomodulatory effects, particularly in the prevention and treatment of upper respiratory tract infections (Barnes et al. 2005). It is not known which one of Echinacea's many chemical components might be responsible for its health benefits. Current information suggest that the immunostimulatory activity of Echianacea species depends on the combination in the action of caffeic acids derivates and alkylamides, although the mechanism of action of these compounds on immune function has not been documented (Herman et al. 2003). There are, however, differences in the constituent profile of the three species. Evidence from preclinical studies supports some of the traditional and modern uses for echinacea, particularly the reputed immunostimulant (or immunomodulatory) properties. Several, but not all, clinical trials of echinacea preparations have reported effects superior to those of placebo in the prevention and treatment of upper respiratory tract infections. However, evidence of efficacy is not definitive as studies have included different patient groups and tested various different preparations and dosage regimens of Echinacea (Barnes et al. 2005).

Echinacea has been attributed the ability to boost the body's immune system and protect the body against infections. The roots, the leaves or the whole plant may be used in the dietary supplement preparation. Echinacea may be best know as an immunostimolat in healthy or in immunosuppresed animals. In vivo studies showed effects in increase phagocytosis, chemotaxis and oxidative burst of neutrophilis and macrophages (Percival 2000).

Preliminary studies are conducted in horse. According to $\mathrm{O}^{\prime} \mathrm{Neill}$ and others, the use in the of Echinacea angustifolia extract for a periods of 42 days lead to haematinic properties, i.e. an agent which improves the quality of the blood by increasing haemoglobin levels and number of erythrocytes, and which, by virtue of their effects on oxygen transport cells, are considered to improve parameters of exercise physiology and performance. It also increases the number of lymphocytes, decreases the number of circulating neutrophilis and improves the fagocytic function of isolated neutrophilis $\left(\mathrm{O}^{\prime} \mathrm{N}\right.$ eill et al. 2002). Further research is required to confirm the blood change, even because the effect may depends on processing procedure of extract, the parts ad kinds of species that was used (Herman et al. 2003) and the metabolic state of the horse.

However, further investigation and surveillance to establish the safety profiles and the potential to interact with conventional medicines for Echinacea preparations are required both in human and horse.

\section{Improving performances}

Horse owners and trainers are always looking for substances that can improve the athletic performance in general.

One of the most widespread herbal product well known for its multipurpose use in the horse is garlic. Garlic is one of the first plant called "performance-enhancing" agents. In fact, garlic was fed to ancient Greek athletes before they competed, because it was associated with strength and work capacity (Rivlin 2001). The plant and its constituents have wellcharacterized antibacterial, antiviral, antiparasitic, antifungal antithrombotic, anticancer and hypoglycaemic properties (Perarson et al. 2006).

Garlic is used as an ingredient or supplement in a numer of feedstuffs. However, there are some preliminary studies that report garlic toxicity for horses. According to Pearson et al. (2006), this plant is potentially toxic when horses are chronically fed with garlic. In particular horses consuming increasing amounts of freeze-dried garlic (FDG) had haematological findings that were indicative of Heinz body anaemia. In particular biochemical and hematologic findings that were indicative of garlic toxicosis were evident 4 days after consuming $0.20 \mathrm{~g}$ of FDG $/ \mathrm{kgBW}$ twice daily. All the features of toxicosis are correlated with the Heinz body anemia, and consist in the presence of Heinz bodies, decrease in hematocrit, RBC count, blood hemoglobin concentration and MCV. The same effect can be also observed in dog consuming $5 \mathrm{~g}$ of fresh garlic/Kg (Pearson et al. 2005, Yamato et al. 2005). Toxic effects are caused, at least in part, by oxidative damage of RBCs (Pearson et al. 2005, Lee et al. 1999). Other authors report that the use of dry garlic feeding can cause skin troubles in horses (Miyazawa et al. 1991). Then, in absence of regulatory control over garlic inclusion rates it exits a potential risk for intoxication when commercial garlic products are used especially in particular condition such as debilitated horses (Valle and Padalino 2006).

Further research are required to study the correct dose to obtain only beneficial effect of garlic.

Other products are promoted as multi-purpose performance enhancers and contain Schizandra chinensis. Schizandra bail (Schizandraceae family) is a plant that grows wild in far Eastern countries (Ahumada et al. 1989). It is used traditionally as adaptogenics aid that is able to assist the normalization of body system function altered by stress rather than exerting a stimulatory effect (Bucci 2000). In accordance with Ahumada et al. (1989) Schisandra exhibits a remarkable effect on the physical performance of race horses in particular on speed, heart rate, quick recovery respiratory frequency and lower lactate values. Furthermore it accelerates the recovery of muscular metabolism (Hancke et al. 1996).

In a recent study on a rehydrating supplement containing Schizandra extract on Standardbred performing early training, no effects were recorded on $\mathrm{VO}_{2}$ max, $\mathrm{HR}_{4}, \mathrm{~V}_{4}$ and $\mathrm{V}_{200}$ (Valle et al. 2005). In the same study, treated animals had lower GGT values at rest, and showed a lower increase of CPK after a normal session of training in respect to the control group. These findings were in accordance to those obtained by Hancke that treated horses with Schizandra chinensis, 
and found that this plant facilitates the recovery of sport horses in training that show high levels of transaminases and CPK (Hancke et al. 1996).

This data are only preliminary studies on the real effect of Schizandra in the horse. Further investigation are required to investigate the real effect of standardized extract are required. Infact is not possible compare the data obtain from the different studies that are now available, because the presence or lack of effect could depend of many aspect such as kind of extract used and dosage.

\section{Improve antioxidant status and general stress}

In accordance with Moffarts et al. (2005) it exists a relationship between exercise and oxidative tissue damage occurring in man and animals. A cellular damage can be created by ROS action. These compounds are generated during exercise in mitochondria, in the activate phagocytes during inflammation and by several enzymes. Their action, if not balanced by antioxidant defence, can cause damage on lipids, proteins, carbohydrates and ribonucleic acids.

It contributes to accelerate muscle fatigue and muscle fibre damage, leading to exercise intolerance and poor performance. They have also a pivotal role in the pathogenesis of chronic inflammatory airway disease. According to Moffarts et al. (2004), horses have experience of oxidative stress during short term exercise and during racing, which in turn induces significant modifications of antioxidant status and in particularly on glutathione system.

Adequate training and dietary adequate supplements can improve antioxidant defences. Nutritional antioxidant supplementation might reduce oxidative damage by enhancement of antioxidant defence, thereby modulating inflammatory defences (Kirschvink et al. 2002). An increased free radical scavenging capacity reduces the free radical increase following physical exercise (Avellini at al. 1999). Then the risk of cell damage and exercise-induced myopathies and haemolysis linked to this phenomenon can be reduced.

This consideration is the basis on which producers presented many antioxidant products for sport horses to the market. Different natural compounds are utilized for those horses premixes; in this review we will discuss flavonoids that are found in vegetables and fruits (e.g citrus, soybean), and a great variety of herbs such as aromatic herbs (mint, rosemary, thyme), and spices (Pietta 2000). Apart from their physiological role in horse as normal components of their diet, nowadays flavonoids are considered to play important metabolic roles. Several studies point out the protective effect of these substances. They have been shown to be anti-carcinogenic, anti-aging, and to promote structure and function in the circulatory system. So they can act as important factors for the resistance against chronic diseases (Pietta 2000, Fernandez at al. 2006).

The use of antioxidant to prevent exercise-induced oxidative lesions is widely practiced in human athletes. However, more studies about oxidative stress are required because there is not enough evidence to state the flavonoids nutritional need in proper way. A few studies are reported in horse either on the use of purified single bioflavonoid extracts (e.g. quercetine and rutine) or on the use of whole plant herbal extracts containing flavonoids. The preliminary studies in the horse failed to find the anecdotic referred positive correlation between bioflavavonoids use and some performance parameters. In particular in accordance to Wooden et al. (1984) hesperidin complex and lemon bioflavonoids complex had no effect on the growth and development of foals, on daily gain and height during growing and training. According to Sweeney and Soma (1984), bioflavonoids showed no effect on exercise-induced pulmonary haemorrhage (bleeding) in Thoroughbred horses. However more studies are required to evaluate the real effect particularly on the antioxidant status of horse.

Other plant based supplements containing antioxidant compounds are used to promote horse wellness in chronic pain, for example Uncaria tomentosa, a Peruvian herb commonly known as "cat's claw" belonging to the family of Rubiaceae. Traditionally its bark containing polyphenols and many other substances is utilized in the treatment of arthritis, bursitis and gastroenteric disorder and for its antioxidant properties (Setty and Sigal 2005).

In practice the extract of Uncaria tomentosa is often associated with other plants extracts that are claimed for their antiinflammatory properties such as Harpagophytum procumbens. The latter is a perennial plant belonging to the family of Pedaliaceae. The leading compound harpagoside, belongs to iridoids glycoside family and accounts for much of the extract's effect; however, it obviously depends also on the extraction process, because the end product contains differing fraction of constituent with agonistic, antagonistic, synergic, or complementary analgesic or antiiflammatory properties (Setty and Segal 2005, Wirth et al. 2005).

Different investigations evaluated the anti-inflammatory and analgesic effects of these extracts, with inconsistent and/or contradictory result.

Only one study tested the effect of single extract of Harpagophytum in the horse. In accordance to Motavon (1994) a preparation contain Hapagophytum extract was tested for the treatment of bone spavin. However the studies include only clinical trial in a very long experimental periods (84 days). During this periods horses were submitted to activity reduction that could be a confounding factor for the clinical exams of lameness.

\section{Improve attention}

Nowadays there is an increasing attention to horse behaviour. In fact there are many behavioural changes that are recognised symptoms of specific dietary deficiencies or toxicity or related to modern management. Excess excitbility is a threat for the correct management of a sport horse, especially because the competition level is widely increased. Moreover coolness and concentration is required during all competition. Owners are prone to use a commercial calming supplement. This is in fact more easy than to try understanding the real problem of the horse and modify diet and management (Harris 2004). For this reason many products are sold on the market, with different composition. In particular they contain tryptophan, magnesium and vitamin B mixed with different herbs. 
For many of the herbs used there is little or no study about efficacy or security; however it is important to point out that valerian is reported in the list of prohibited substance of FEI (prohibited substances medication class a): "valerian and other herbal products other than those listed as prohibited." Valeriana officinalis is a diffuse plant native to Europe and North Asia. The roots and rhizomes are traditionally used as a sedative for human restlessness and sleeping (Muller and Klement 2006) (Eadie 2004). It contains a variety of compound and in particular valerianic acid, that is also contained in other herbs.

St. John's-wort (Hypericum perforatum) is another herb whose extract is used in horse supplements. This herb is used in human therapy of mild to moderate depression (Wurglics et al. 2006). St. John's-wort contains hypercin, a pigment that is absorbed by the body, and can cause skin lesions of photosensitization in animals an in particular in the horse (Petazzi et al. 2002, Chabchoub et al. 1999).

\section{Discussion and Conclusion}

Herbal products provide an important resource for maintaining and improving health of horse (Percival 2004). They are considered since many times as natural ergogenics aids; however limited scientific evidences are available to postulate that many herbal products have ergogenic effect for horse. They are also considered safe per se; however, natural is not synonymous of safe. In the last years, some studies report some undesirable side effects of some plant based products for horses, such as garlic and Hypericum (Percival et al. 2005, Chabchoub et al. 1999). More studies are needed to identify the real effect of many plants in the horse.

The majority of herbal controlled trial publications are performed on other animals than horse and did not include information about the quality of the herbal product studied. This lack of reporting is cause of the well-documented quality-control problems in the herbal supplement industry (Wolsko et al. 2005) and of the different result that are reported on the studies available not also in the horse but for other animals and humans too. The different ways to obtain herbal product can influence the chemical composition of the end product and bias the biological effect both for in vivo and in vitro studies; the manufacturing process can also influence the composition of the end products. For example garlic product can contain essential oil or garlic oil macerate, rather than garlic powder or garlic extract. This compound contain different substances which can exert different biologic effect (Amagase et al. 2001).

The making process to obtain herbal products or extract can increase or decrease the potency and bioavailability of various crude herbs, and modify the characteristic of the final products (Amaganese et al. 2006).

Even if standardization is the key to assess consistent quality and efficacy, this term is not a synonymous of safety for the consumer. Infact the definition of "standardized" varies widely, and there is no published empirical evidence that "standardized" products have different quality than "non-standardized" products (Ernst 2002).

More studies in the animal field an in particular in the horse are necessary to understand what are the real effect of herbal products. Only in this way the feedststuff industries can attend the Good Manufacturing Practice rules for dietary supplements to help ensure dietary supplement "identity, purity, quality, strength and composition" and to prevent potential contamination (Ernst 2002).

At the moments many industries, both food and drugs producing companies, have taken advantage from using herbal products and developing new products which claims to ensure a healthy life for the animal without certificated studies in the horse. These studies are however necessary not also to prevent adverse effect but also to prevent interactions between herbs and drugs or doping control.

In fact, it is also really important to point out that a plant product can be considered part of a supplement or a drug, and even to have doping effect. Anti-doping rules are severe, and changed considerably in the last times. For this reason, it is important to update the knowledge on the products that are available on the market. As a matter of fact, many herbal derived substances are already included in the forbidden substances list: theobromine, valerian and gamma-oryzanol are common supplements ingredients but they are now considered doping substances.

Both the horse and the owner must be protected against unknown secondary effect of herbs, interactions and antidoping rules. Too less information are available for vet practitioners and owners, with an increasing risk of problems.

Then, a lot of work is still to be performed on the area of herbal products and their use in horses, for two main reasons: from one hand, it is important, as described, to avoid risks in the use of these products; on the other, the lack of information is one of the reasons why these products, very often used since centuries as the basis of different ethnical medicines, are not widespread as they could be if satisfactory studies were available.

\section{References}

Abebe W. J. (2002): Herbal medication: potential for adverse interactions with analgesic drugs. Journal of Clinical Pharmacy and Therapeutics 27, 391-401

Ahumada F., Hermosilla J., Hola R., Pena R., Bitter F.,Wegmann E., Hancke J. and Wikman G. (1989): Studies on the effect of Schizandra chinenensis extract on the horse submitted to exercise and maximum effort. Phytotherapy Research 3, 175-179

Amagase H. (2006): Clarifying the real bioactive constituents of garlic. Journal of Nutrition 136, 716S-725S

Amagase H. , Petesch B. L. , Matsuura H. , Kasuga S. and Itakura Y. (2001): Intake of garlic and its bioactive components Journal of Nutrition 131, 955-962

Avellini L., Chiaradia E. and Gaiti A. (1999): Effect of exercise training, selenium and vitamin $E$ on some free radical scavengers in horses (Equus caballus). Comparative Biochemistry and Physiology 123, 147-154

Barnes J., Anderson L. A., Gibbons S. and Phillipson J. D. J. (2005): Echinacea species (Echinacea angustifolia (DC.) Hell., Echinacea pallida (Nutt.) Nutt.,Echinacea purpurea (L.) Moench): a review of their chemistry, pharmacology and clinical properties. Journal of Pharmacy Pharmacology 57, 929-954

Bergero D. (2004): New insights related to the nutritional managemet of endurance horses. Proceeding of the Second European Equine Health \& Nutrition Congress. 41-50

Bucci L. R. (2000): Selected herbals and human exercise performance. American Journal of Clinical Nutrition 72, 624S-626S 
Chabchoub A., Landolsi F., Lasfar F., Amira A. and Bousrih A. (1999): Photosensitization and keratitis in the Arabian thoroughbred horse. Revue de Médecine Vétérinaire 150, 617-624

Coenen M. (1998): Review of nutritional conditions of horses and cattle as a tool in veterinary services animal welfare procedures. Dtsch Tierarztl Wochenschr. 105, 124-127

Craig W. J. (1999): Health-promoting properties of common herbs. American Journal of Clinical Nutrition 70, 491s-499s

Eadie M. J. (2004): Could Valerian have been the first anticonvulsant? Epilessia 45, 1338-1343

Ernst E. (2002): The risk-benefit profile of commonly used herbal therapies: ginkgo st john's wort ginseng echinacea saw palmentto and kawa. Complemntary and Alternative Medicine Series 136, 42-53

FEl Equine Prohibited List on http://www.horsesport.org

Fernandez S. P., Wasowski C., Loscalzo L. M., Granger R. E., Johnston G. A., Paladini A. C. and Marder M. (2006): Central nervous system depressant action of flavonoid glycosides European Jurnal of Pharmacology 539 168-176

Halsted H. C. (2003): Dietary supplements and functional foods: 2 sides of a coin? American Journal of Clinical Nutritional 77. 1001S-1007S.

Hancke J. L., Burgos R. A., Caceres D., Brunetti F., Durigon A. and Wikman $G$. (1996): Reduction of serum hepatic transaminases and CPK in sport horses with poor performance treated with a standardized Schizandra chinensis fruit extract. Phytomedicine 3, 237-240

Harris P. A. and Harris R. C. (2005): Ergogenic potential of nutritional strategies and substances in the horse. Livestock Production Science 92, 147-165

Hermann J. R., Honeyman M. S., Zimmerman J. J., Thacker B. J., Holen P. J. and Chang C. C. (2003): Effect of dietary Echinacea purpurea on viremia and performance in porcine reproductive and respiratory syndrome virus-infected nursery pigs. Journal of Animal science 81, 2139-2144

Hines M. T., Schott H. C., Bayly W. M. and Leroux A. J. (1996): Exercise and immunity: a review with emphasis on the horse. Journal of Veterinary Internal Medicine 10, 280-289

Horohov D. W., Dimock A., Guirnalda P., Folsom R. W., McKeever K. H. and Malinowski K. (1999): Effect of exercise on the immune response of young and old horses. American Journal of Veterinary Research 60, 643-647

Kirschvink N., Fievez L., Bougnet V., Art T., Degand G., Smith N., Marlin D., Roberts C., Harris P. and Lekeux P. (2002): Effect of nutritional antioxidant supplementation on systemic and pulmonary antioxidant status, airway inflammation and lung function in heavesaffected horses. Equine Veterinary Journal 34, 705-712

Lampe J. W. (2003): Spicing up a vegetarian diet: chemopreventive effects of phytochemicals. American Journal of Clinical Nutrition 78, 579S-583S

Lee K. W., Yamato O., Tajima M., Kuraoka M., Omae S. and Maede Y. (2000): Hematologic changes asociated with the appearance of eccentrocytes after intragastric administration of garlic extract to dogs. Am J Vet Res 61: 1446-1450

Miller A. L. (1996): Antioxidant Flavonoids: Structure, Function and Clinical Usage. Alternative Medicine Review 1, 103-1 11

Miyazawa K., Ito M. and Ohsaki K. (1991): An equine case of urticaria associated with dry garlic feeding. Journal of Veterinary Medical Science 53, 747-748

Moffarts B. de, Kirschvink N., Art T., Pincemail J. and Lekeux P. (2005): Effect of oral antioxidant status in trained thoroughbred horses. Vet J 169, 65-74

Moffarts B. de, Kirschvink N., Art T., Pincemail J. and Lekeux P. (2004): Deficiency of the glutathione system in the racehorse. Proceedings of 30ème journée de la recherche équine, 77-83

Montavon S. (1994): Efficacy of a medicinal plant preparation based on Harpagophytum procumbens in cases of bone spavin of adult horses. Pratique Vétérinaire Équine 26, 49-53

Muller S. F. and Klement S. (2006): A combination of valerian and lemon balm is effective in the treatment of restlessnet and dyssomnia in children. Phytomedicine 13, 383-387

Naganuma M., Saruwatari A., Okamura S. and Tamura H. (2006): Turmeric and curcumin modulate the conjugation of 1 -naphthol in caco-2 cells. Biological \& Pharmaceutical Bulletin 29, 1476-1479
O’Neill W., McKee S. and Clarke A. F. (2002): Immunological and haematinic consequences of feeding a standardised Echinacea (Echinacea angustifolia) extract to healthy horses. Equine Veterinary Journal 34, 222-227

Percival S. S. (2000): Use of Echinacea in Medicine. Biochemical Pharmacology 60, 155- 158

Person W., Boermans H. J., Betteger W. J., McBride B. W. and Lindinger M. I. (2005): Association of maximum voluntary dietary intake of freeze-dried garlic with Heinz body anemia in horses. Am J Vet Res 66, 457-464

Petazzi F., Rubino G., Pieragostini E. and Giordano G. (2002): Photosensitization caused by Hypericum species. Changes in the blood proteins of lonica goats. Summa 19, 25-27

Pietta P. G. (2000): Flavonoids as antioxidants. Journal of Natural Production 63, 1035-1042 Review

Rivlin R. S. (2001): Historical perspective on the use of garlic. Journal of Nutrition 131, 951S-954S

Sener G., Kabasakal L., Atasoy B. M., Erzik C., Velioglu-Ogunc A., Cetinel S., Gedik N. and Yegen B. C. (2006): Ginkgo biloba extract protects against ionizing radiation-induced oxidative organ damage in rats. Pharmacology Research 53, 241-252

Setty A. R. and Sigal L. H. (2005): Herbal medications commonly used in the practice of rheumatology: mechanisms of action, efficacy, and side effects. Seminars in Arthritis and Rheumatism 34, 773-784

Sweeney C. R. and Soma L. R. (1984): Exercise-induced pulmonary hemorrhage in Thoroughbred horses: response to furosemide or hesperidin-citrus bioflavinoids. Journal of the American Veterinary Medical Association 185, 195-197

Tsao R. and Akhtar M. H. (2005): Nutraceuticals and functional foods: current trend in phytichemical antioxidant research. Journal of Food, Agriculture \& Environment 3, 10-17

Valle E. and Bergero D. (2005): Un'analisi critica dell'uso degli estratti d'erbe nel mercato del cavallo in Italia. Proceedings SIDI, June 22-23, 347-356

Valle E., Padalino B., Costantini M., De Palo P., Siccardi E. and Bergero D. (2006): Valutazione dell'effetto del lavoro e dell'efficacia di un integratore polifunzionale in cavalli trottatori in allenamento precoce. Ippologia, in press

Valle E. and Padalino B. (2006): Un caso di intossicazione da aglio. Proceedings SIVE January 28-29, 181

Wirth J. H., Hudgins J. C. and Paice J. A. (2005): Use of herbal therapies to relieve pain: a review of efficacy and adverse effects. Pain Management Nursing 6, 145-167

Wolsko P. M, Solondz D. K., Phillips R. S., Schachter S. C. and Eisenberg D. M. (2005): Lack of herbal supplement characterization in published randomized controlled trials. American Journal Medicine 118, 1087-1093

Wooden G. R., Crane C. S. and Beisel C. G. (1984): An investigation of the effect of hesperidin complex and lemon bioflavonoid complex on growth and development of thoroughbred horses. Journal of Animal Science 59, 1529-1535

Wurglics M. and Schubert-Zsilavecz M. (2006): Hypericum perforatum: a 'modern' herbal antidepressant: pharmacokinetics of active ingredients. Clinical Pharmacokinetics 45, 449-468

Yamato O., Kasai E., Katsura T., Takahashi S., Shiota T., Tajima M., Yamasaki M. and Maede Y. (2005): Heinz body henolytic anemia with eccentrocytosis from ingestion of chinese chive (allium tuberosum) and garlic (allium sativum) in a dog. Journal of the American Animal Hospital Association 41, 68-67

Zanoli P. (2004): Role of hyperforin in the pharmacological activities of St. John's Wort., CNS Drug Rev 10, 203-218

Zeisel S. H. (1999): Regulation of nutraceuticals. Science,285, 1853-1855

Domenico Bergero

Department of Animal production, epidemiology and ecology

University of Turin

Via Leonardo da Vinci 44

10095 Grugliasco (TO), Italy

domenico.bergero@unito.it 